\title{
Bleeding from the Alimentary Canal During the Management of Spinal Cord Injury Patients
}

Professor Jerzy Kiwerski, M.D.

Rehabilitation Clinic of Warsaw Medical Academy, Konstancin, Poland.

\section{Summary}

In the years 1970-1984, among 2000 patients with spinal cord injuries treated in our clinic, 52 had severe haemorrhage from the alimentary canal. They mainly concerned patients without a peptic ulcer history. This study gives an analysis of this group of patients with the description of the level and of the degree of spinal cord injury, the time of the onset of the haemorrhage, the pharmacological treatment applied that could influence the occurrence of bleeding and the results of the treatment.

Bleeding most of ten occurred in patients with a complete injury of the cervical spinal cord during the early post-injury period. It is probably due to a severe disturbance of autonomic system function. It appears that the use of anticoagulants and of steroids can predispose to the occurrence of bleeding, but it is not the basic factor. Diagnostic difficulties in these patients causing a delay in the onset of proper treatment are stressed. Key words: Spinal cord injury; Alimentary canal haemorrhage

\section{Introduction}

Haemorrhages from the alimentary canal are an infrequent but dangerous complication of spinal cord injury. The incidence of bleeding is between $5 \%$ and $7 \%$ of the spinal cord injured patients (Guttmann 1973; Miller et al. 1975; Nuseiben 1976, Stremple et al., 1973) but Perret and Solomon (1971) report these complications in as many as $22 \%$ of patients treated for cervical spinal cord injury. The disparity in the data may be due to differences in the clinical material, the location and degree of the spinal cord injury, and to the method of treatment. Over the past few years the number of these complications has increased in line with the growing number of people suffering from peptic ulcer and with treatment by anticoagulants and steroids (Hamza and Den Besten 1972; Ingberg and Prust, 1968; Miller et al, 1975; Nuseiben, 1976). 


\section{Clinical material}

In the years 1970-1984 over 2000 patients with spinal cord injuries were treated in our Spinal Cord Injury Department. In 52 of those patients $(2.6 \%)$ serious bleeding from the alimentary canal was observed. Slight episodic bleeding has been disregarded. The overwhelming majority of the analysed group consisted of male patients, which is only to some extent accounted for by dominance of male patients in the whole series. In women haemorrhages were only observed in the older age group (over 50).

Table 1 presents the level of spinal column injury and the degree of spinal cord injury. Haemorrhage from the alimentary canal usually occurs in patients with cervical spinal cord injuries, which constitute over $80 \%$ of the presented material Bleeding was most frequent in patients with complete spinal cord injuries.

Table 1

\begin{tabular}{cccccc}
\hline $\begin{array}{c}\text { Level of } \\
\text { Spinal } \\
\text { Injury }\end{array}$ & Complete & $\begin{array}{c}\text { Degree of Spinal Cord Injury } \\
\text { Partial }\end{array}$ & Total \\
\hline $\mathrm{C}_{2}-\mathrm{C}_{4}$ & 4 & 2 & 4 & - & 10 \\
$\mathrm{C}_{5}-\mathrm{C}_{7}$ & 27 & 2 & 2 & 1 & 32 \\
$\mathrm{Th}_{1}-\mathrm{Th}_{6}$ & 2 & - & 1 & 1 & 4 \\
$\mathrm{Th}_{7}-\mathrm{Th}_{12}$ & 5 & - & - & - & 5 \\
Below & 1 & - & - & - & 1 \\
\hline Total & 39 & 4 & 7 & 2 & 52 \\
\hline
\end{tabular}

\section{Factors Influencing the Incidence of Bleeding}

Bleeding from the alimentary canal may often occur in spinal cord patients who have not previously complained of digestive system disorders. Nuseiben (1976) reported no previous peptic ulcers in seven patients with bleeding; in our material only seven patients had previously been treated for such ailments. Hamza and Den Besten (1972) claim that the acidity of the gastric content may increase and finally lead to peptic ulcer formation. Guttmann (1973) and Perret (1971) are of the opinion that bleeding in cervical spinal cord injured patients depends upon the dominance of the vagus nerve, subsequent to the inactivity of the sympathetic system in spinal shock. Sales (1972) suggests that lesions of the mucous membrane of the stomach or duodenum (usually in the form of numerous small erosions) may be dependent upon disturbance of blood flow leading to mucous membrane hypoxia. Nuseiben (1976) recorded paleness, ischaemia and focal lesions of the mucous membrane of the stomach as early as 24 hours after spinal cord injury. While considering the factors bearing an influence upon the incidence of bleeding in our patients we pay attention to the level and degree of spinal cord injury and the question of antithrombotic and steroid treatment.

Table 2 presents the degree of spinal cord injury and the time elapsing from the injury to the onset of bleeding from the alimentary canal. This kind of complication is most frequently observed in complete spinal cord injuries. It is in such cases, especially if the injury is located in the cervical or upper thoracic segment, that 
Table 2

\begin{tabular}{lccccc}
\hline & \multicolumn{5}{c}{ Degree of Spinal Cord Injury } \\
\cline { 3 - 6 } Time Elapsing from Injury & & \multicolumn{3}{c}{ Partial } & \\
to Bleeding & Complete & B & C & D & Total \\
\hline up to one week & 4 & 1 & - & - & 5 \\
2-3 weeks & 18 & 2 & 4 & 1 & 25 \\
$4-6$ weeks & 13 & 1 & 3 & 1 & 18 \\
$7-12$ weeks & 4 & - & - & - & 4 \\
\hline Total & 39 & 4 & 7 & 2 & 52 \\
\hline
\end{tabular}

Table 3

\begin{tabular}{lccccc}
\hline & \multicolumn{5}{c}{ Ulceration confirmed } \\
\cline { 2 - 6 } Pharmacotherapy used & Clinically & $\begin{array}{c}\text { Clinically } \\
+ \text { X-ray }\end{array}$ & Surgically & $\begin{array}{c}\text { Post } \\
\text { Mortem }\end{array}$ & Total \\
\hline Aspirin & 8 & 3 & 1 & 1 & 13 \\
Other Anticoagulants & - & 2 & 1 & - & 3 \\
Steroids & 1 & 1 & 2 & 6 & 10 \\
Anticoagulants + Steroids & 2 & 2 & 1 & 2 & 7 \\
No Pharmacotherapy & 4 & 5 & 4 & 6 & 19 \\
\hline Total & 15 & 13 & 9 & & 52 \\
\hline
\end{tabular}

the disturbances of balance between the sympathetic and parasympathetic system are most severe and prolonged (Chorobski, 1953; Haftek et al., 1968; Kiwerski, 1974), and the undernutrition of the tissues is most marked. Bleeding was sometimes recorded as early as in the first week after injury and was most frequent within six weeks of the injury. This incidence is probably due to disturbances in the function of the autonomic neurons system which recede or decrease markedly with the decline of spinal shock. After six weeks following the injury bleeding was only noted in patients with complete spinal cord injury, and in 3 out of 4 patients with a past history of peptic ulcer.

Table 3 presents the routine treatment by antithrombotic agents and steroids, including the methods of diagnosing bleeding ulcers of the alimentary canal. This Table apparently confirms the claim that anticoagulants and steroid treatment is responsible for the alimentary canal bleeding (Hamza and Den Besten, 1972; Ingberg and Prust, 1968; Miller et al., 1975). It appears however, that these pharmacological agents are not the sole factors although they undoubtedly increase the tendency to ulcer formation. In our clinical material serious alimentary bleeding was recorded in 19 patients who were not exposed to pharmacological therapy by any of the above agents. It should be stressed that over the last decade, anticoagulant therapy was instituted (as a rule), to patients surgically treated, and frequently to those treated conservatively. Steroids were administered to the majority of patients, particularly if there was considered to be severe injury to the spinal cord. Hence, the group of patients without these particular forms of pharmacotherapy far less numerous than those pharmacologically treated.

Table 4 presents the results and methods of treatment. The results of treatment are often unsatisfactory, with the mortality being as high as $37 \%$. The ulcers are usually, difficult to diagnose on account of the absence of characteristic symptoms. 
Table 4

\begin{tabular}{lccc}
\hline Method of & \multicolumn{2}{c}{ Results of Treatment } & Total \\
Treatment & Favourable & Death & 42 \\
\hline Non-surgical & 28 & 14 & 10 \\
Surgical & 5 & 5 & 52 \\
\hline Total & 33 & 19 & 5 \\
\hline
\end{tabular}

Thus, appropriate management is often delayed (Charney et al., 1975; Ingberg and Prust, 1968; Lucas et al., 1971), leading to poor results both in patients treated with or without a spinal operation.

\section{Conclusions}

I. Bleeding from the alimentary canal is not frequent but is a dangerous complication in spinal cord injury patients, usually affecting patients who have no past history of peptic ulcer disease.

2. Bleeding is more often seen in patients who have a complete cervical spinal cord injury, and is probably due to a severe and prolonged disturbance of the balance between the sympathetic and parasympathetic systems.

3. The use of anticoagulants and steroids increases the risk of alimentary canal bleeding but is not essentially responsible for its occurrence.

4. Early diagnosis is usually difficult, and delay leads to poor results of both conservative and surgically treated patients.

\section{Résumé}

Entre 1970-1984 nous avons traitée dans notre Clinique 2000 cas des lésions de la moelle épiniére. Dans 52 notre malades nous avons observée hémorragie gastro-intestinale. Il s'agissait des malades qui n'ont pas eu anteriéurment aucune traitement d'ulcer de l'estomac.

L'auteur analise cette groupe de complications du point de vue du dégré et niveau de lésion de la moelle, le temp entre la lésion et hémorragie, le traitement médicale qui peuvent provoquer hémorragie et le réşultats du traitement.

Nous avons observée hémorragie gastro-intestinale dans les lésions completes de moelle cervicale, tout précoce aprés l'accident. Probablement c'est liée avec les troubles de fonctions autonomiques et les troubles trophiques.

Nous avons constatée que la thérapie anticoagulant et stéride peuvent jouer une cértain role, ils ne sont pas le facteur principle.

Les difficultés diagnostiques chez notre 52 malades ont rétardée la diagnostique et traitement propre; en $37 \%$ les cas hémorragiques nous avons observée les ré sultats défavourables.

\section{Zusammenfassung}

In der Jahren 1970-1984 unter den 2000 Kranken mit verletztem Rückenmark, die in unserer Klinik behandelt worden sind, bei 52 Patienten stellte man ernsthafte Verdauungskanalblutungen fest. Meistens waren das Kranke, die davor wegen irgendeiner Geschwürkrankheit nicht behandelt worden waren. Unter Berücksichtigung: des Grades und Niveaus der Rückenmarkverletzung, der Zeitspanne zwischen der Verletzung und Blutung angewandten pharmakologischen Behandlungen, die möglicherweise einen Einfluss auf das Auftreten von Blutungen sowie Kurergebnisse haben konnten, wurde diese Patientengruppe analysiert. Die Verdauungskanalblutungen würden überwiegend bei Kranken mit totaler Markverletzung im Halsteil in der frühen Verletzungsperiode, festgestellt.

Der Zusammenhang scheint auf die Funktion des autonomischen und trophischen System, zurückzuführen.

Festgestellt wurde, dass die Anwendung von Antikoagulation und Steroiden prädisponierende Rolle 
spielen kann, ist aber weit nicht die grundsätzliche Ursache für das Auftreten der Verdauungskanal blutungen.

Die diagnostische Schwierigkeiten in bezug auf diese Krankengruppe, verursachten die Verzögerung in der Festelegung der Diagnose und Wahl entsprechender Behandlung, was oftmals ungünstige/ce $37 \%$ Fälle/Behandlungsergebniss zu Folge hatte.

\section{References}

Charney KJ, Juler GL, ComarR AE 1975 General surgery problems in patients with spinal cord injuries. Archives of Surgery, 110, 1083-1088.

CHORÓBSKI J 1953 Sympathetic and parasympathetic system. PZWL, Warszawa.

Guttmann L 1973 Spinal cord injuries. Comprehensive management and research. Blackwell, Oxford.

Haftek J, Chromiec E, KiWerski J 1968 Prevention and treatment of pulmonary complications in acute trauma in the cervical spinal cord. In: Compensation of function spinal cord. PZWL Warszawa, 107-114.

HAMZA KN, Den BESTEN L 1972 Bile salts producing stress ulcers during experimental shock. Surgery, 71, 161-167.

INGBERG HO, PRUST FW 1968 'The diagnosis of abdominal emergencies in patients with spinal cord lesions. Archives of Physical Medicine and Rehabilitation, 49, 343-348.

KIWERSKI J 1974 Cervical spinal cord injuries. In: Treatment of spinal cord injuries. M. Weiss, PZWL - Warszawa.

LuCAS CE, Sugawa C, RIDDlE J 1971 Natural history and surgical dilemma of 'stress' gastric bleeding. Archives of Surgery, 102, 266-273.

Miller LS, StaAs WE, Herbison GJ 1975 Abdominal problems in patients with spinal cord lesions. Archives of Physical Medicine and Rehabilitation, 49, 348-358.

NuSEIBEN JM 1976 Stress ulceration in spinal injuries. In: Vinken PJ, Bruyn GW: Handbook of clinical neurology., 26. Amer. Elsevier Publishing Co. Inc., New York, 351-353.

Perret G, Solomon A 1971 Gastro-intestinal haemorrhage and cervical cord injuries. Proceedings of the 17th Veterans Administration Spinal Cord Conference. Washington, US Government Printing Office., 106-110.

SALES JE 1972 Ischemia as a factor in the aetiology of stress ulceration. British Journal of Surgery, 59, 309-310.

Stremple JF, Mori H, Lev P 1973 The stress ulcer syndrome. Current Problems in Surgery 4, 1-64. 